\title{
Peripheral Solutions to Peripheral Development: The Case of Early 20th Century ROMANIA*
}

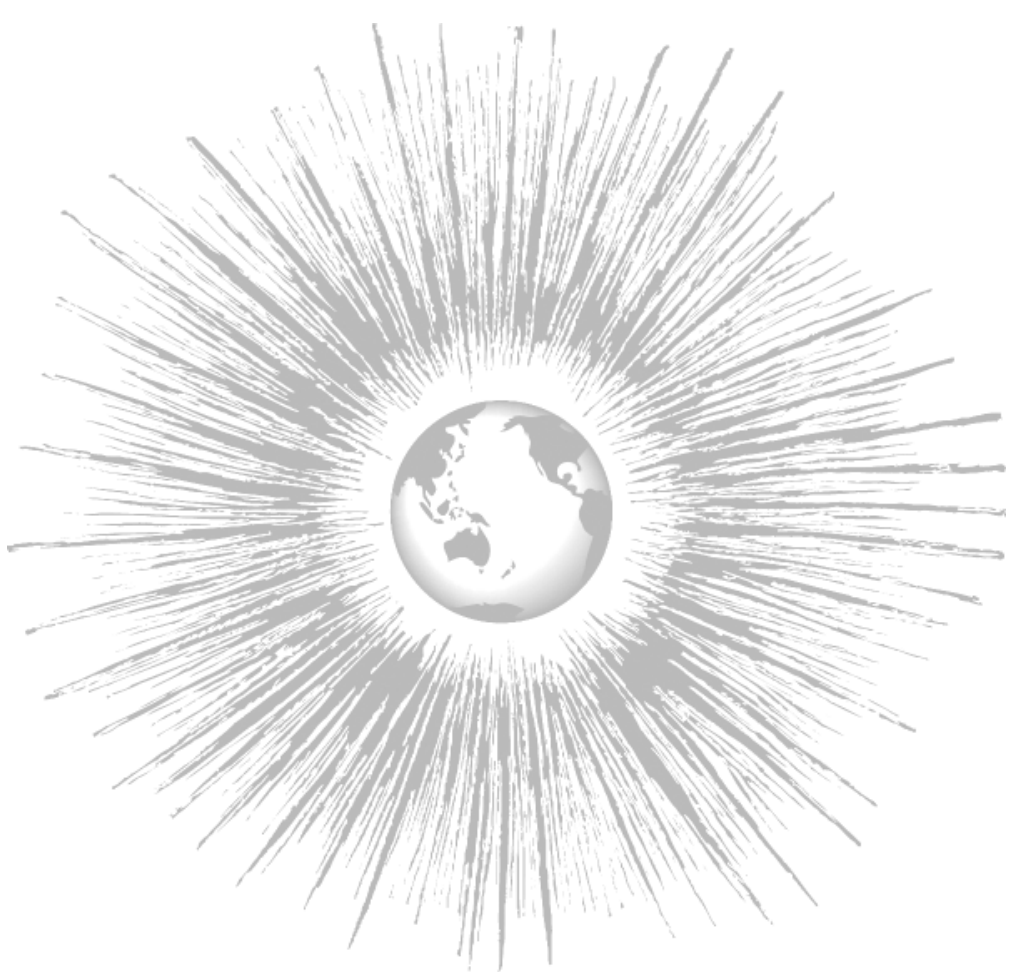

ABSTRACT:

The article furthers the claim that many of the weaknesses of Marxist theory that constituted the starting point of critical approaches from Latin American dependency theory to world-systems analysis had been addressed in very similar terms as early as the igoos. The focus is on intellectual debates in early twentieth-century Romania, especially as engendered by the theory of "forms without substance" as an alternative project of mod ernization for the periphery and the follow-up confrontation between the socialist Constantin Dobrogeanu-Gherea and the Poporanist Constantin Stere on the issue of social and economic development.
Manuela Boatcă

What Wallerstein dubbed the "culs-de-sac into which much Marxist analysis and praxis has fallen," represented, for him, the consequence of Marxism's overemphasis on the role of the urban industrial proletariat, leading it to explain away "the role of (the very existence of) nationalities, peasants, minorities, women, and the whole peripheral zone." As a result, "Nine-tenths of the world became 'questions', 'anomalies', 'survivals'-objectively progressive for a while perhaps, but destined to disappear, sociologically, analytically, politically" (Wallerstein 1991: 160). The debates which these sore points engendered among Western theorists in the second half of the twentieth century, however, had long been fought out in the Eastern European and Latin American peripheries. But while Latin American dependency theory acquired theoretical prominence in the United States during the I970s and later throughout the world, the much earlier contribution of Romanian theorists to modernization debates remains mostly unknown to this day. Within a rather heterogeneous theoretical corpus composed of sociological, economic, and political arguments, many of the abovementioned weaknesses of Marxist theory were explicitly disclosed as early as the I900s. Its most poignant points were made during polemical debates among representatives of competing political camps, as the confrontation between the socialist Gherea ${ }^{\dagger}$ and the poporanist Stere, on which this article will focus, clearly demonstrates.

Manuela Boatcă

Katholische Universität Eichstätt-Ingolstadt

Lehrstuhl für Soziologie

Ostenstr. 26, 85072 Eichstätt

Germany

manuela.boatca@ku-eichstaett.de

* This is the revised version of a paper presented at the Institute for Research on World-Systems (IROWS), University of California at Riverside, in April 2004.

† Gherea, see Dobrogeanu-Gherea, Constantin.

JOURNAL OF WORLD-SYSTEMS RESEARCH, XI, I, JULY 2005, 3-26 http://jwsr.ucr.edu/

ISSN $1076-156 \mathrm{X}$

C) 2005 Manuela Boatcă 
Plate 1 - Romania Today

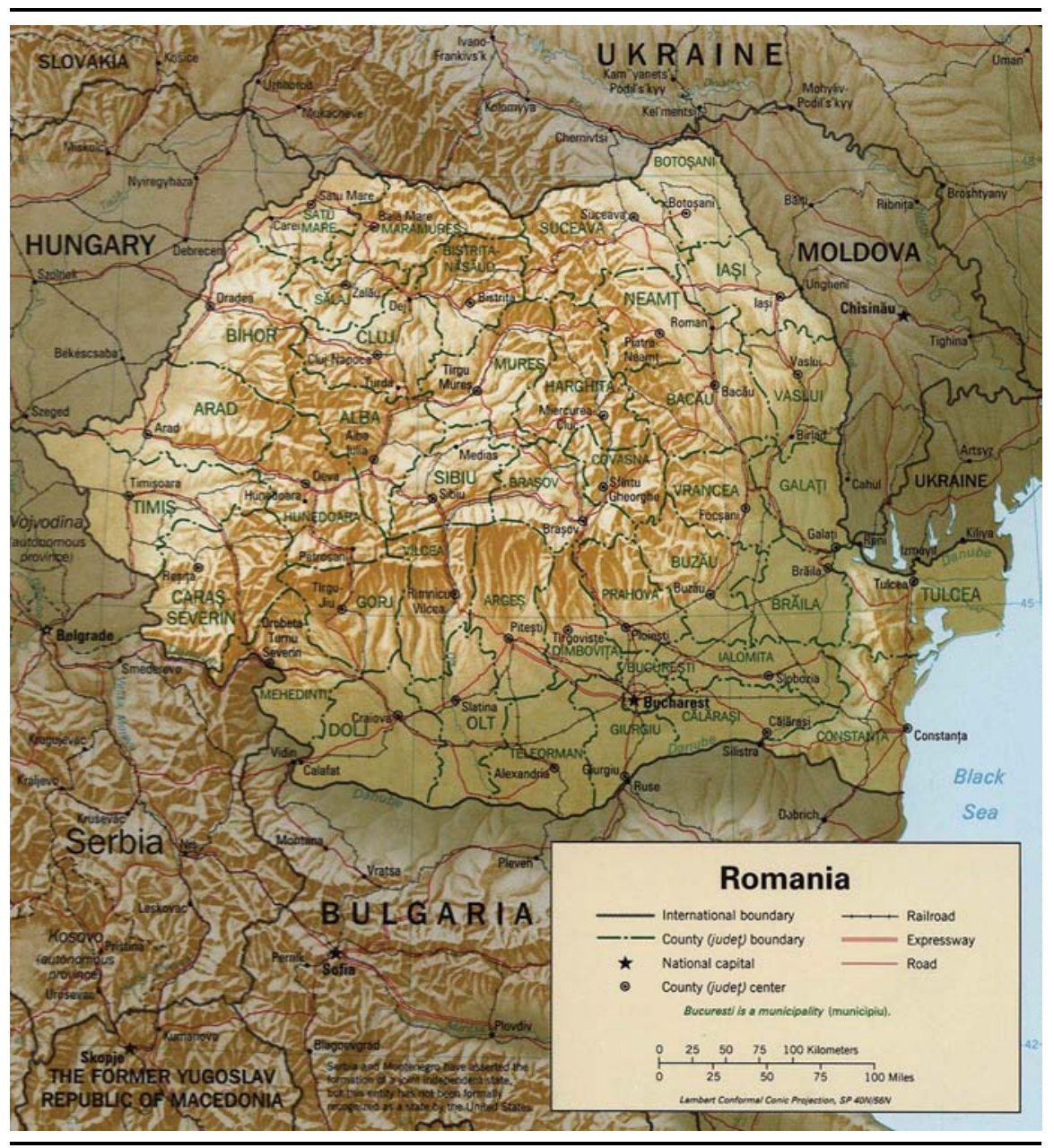

Source: Central Intelligence Agency, Washington, D.C., 1996.

\section{THE HISTORICAL AND GEOPOLITICAL BACKGROUND}

Although never formally colonized, nineteenth-century Romania experienced a situation of economic, political, and, largely, ideological domination that has more than once been characterized as "neocolonialism" (Chirot 1976: 162). In the context of an imperial military threat on the one hand, and the expansion of international capital on the other, development issues for the politically decentralized and economically backward Romanian principalities of the mid-nineteenth century could only be formulated against the backdrop
Plate 2 - Romanian Principalities, 1699-1848

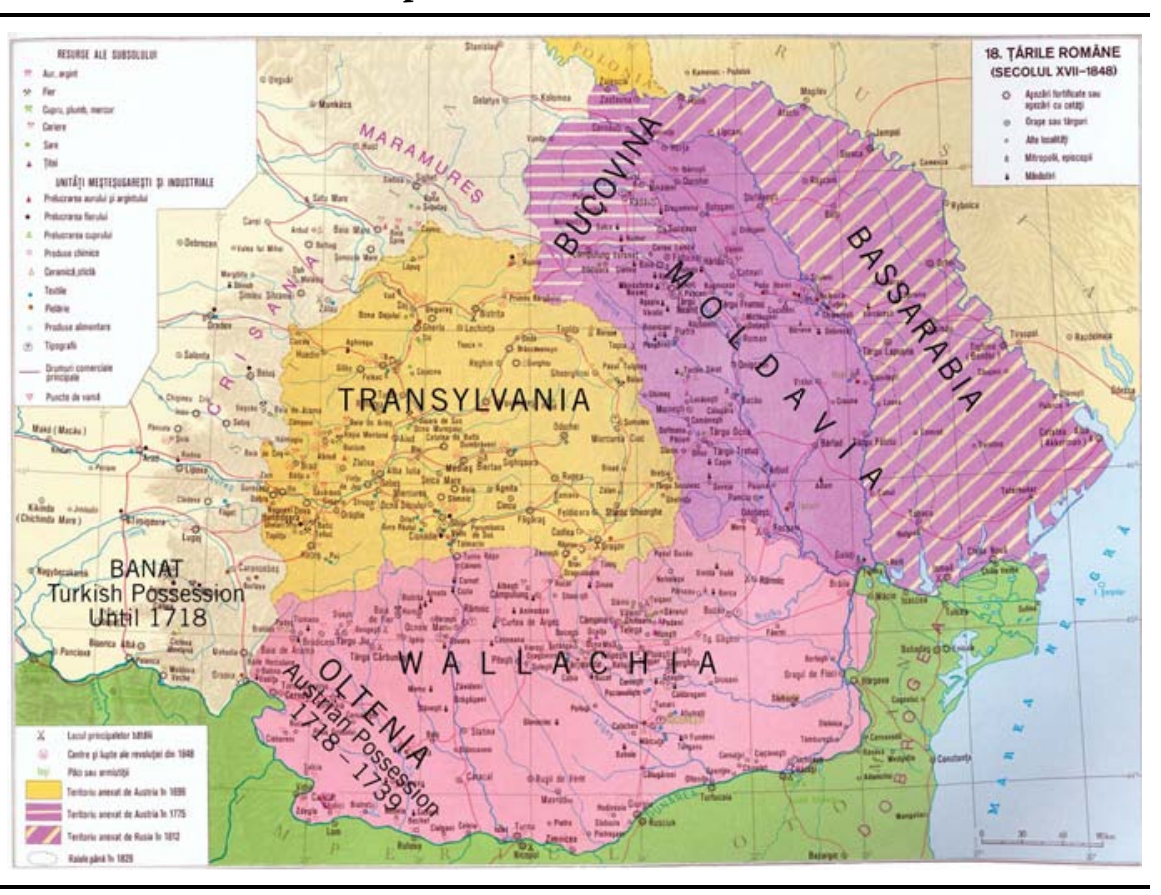

Source: P. $8 \mathrm{I}$ in Romania. Atlas Istorico-Geografic, edited by Academia Română, Institutul de geografie. Bucharest: Ed. Academiei Române, 1996. Reproduced with permission from the Romanian Academy.

of an impending foreign domination and endangered national identity. Thus, the filtering of Western ideological notions through the perspective of national concerns involved, on the one hand, a resignification of European liberalism, conservatism, and Marxism to fit the reality of the Eastern European periphery and to allow sensible predictions about its development, and on the other hand, a reinterpretation of their relationship to one another according to their propensity to either stick to the global design of modernization on the Western model or devise their own, rooted in Romania's local history.

Since the inevitability of progress and the normality of social change were the tenets of both liberalism and Marxism in the core, in Romania they tended to yield a hybrid position combining the assumptions of these two Western ideologies and is thereby illustrative of an explaining away, so to speak, of the anomalies present in the periphery's transition to capitalism. The conservative side, characterized in Romania by a scepticism of the modernization model in both its liberal and its Marxist variant (i.e., of Westernization), was enriched 


\section{Plate 3 - Romanian Principalities, 1859-1914}

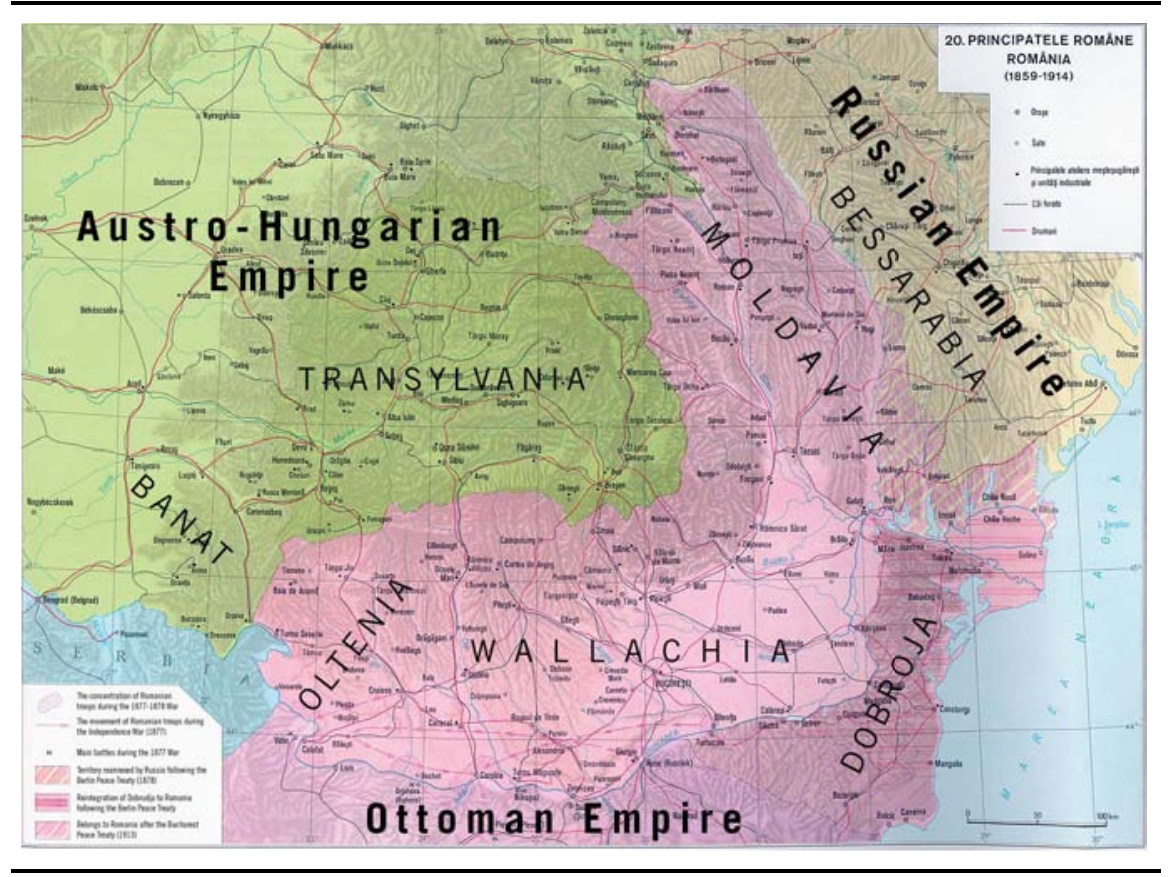

Source: P. 85 in Romania. Atlas Istorico-Geografic, edited by Academia Română, Institutul de geografie. Bucharest: Ed. Academiei Române,I996. Reproduced with permission from the Romanian Academy.

and expanded by such positions as poporanism, ${ }^{1}$ peasantism, and corporatism, all of whose main characteristic was the advocacy of an alternative path of development for peripheral countries.

With Austria-Hungary gradually renouncing its claims to political rule in Romania due to internal 'nationalities' problems within the empire, and with the end of formal Turkish rule as a result of the 1877-78 Romanian War of Independence, the threat of military rule and its actual presence in the Romanian lands had been finally abolished. From then on, it was commercial interests that took precedence over political ones. In Romania's case, these interests involved

1. From the Romanian popor, meaning "people." While its name is the etymological equivalent of "populism," the Romanian "poporanism" had less in common with other populist strands of its time than with the national cultural and political context out of which it emerged. For a detailed account of its intricate relationship with Romanian liberalism and conservatism, as well as with Russian narodnicism and Western populism, see Georgiu (2001), Boatcă (2002), and below. marketable wheat crops and their exploitation according to the capitalist mode of production. Since neither villagers (who had joint rights over communal land) nor boyars (a primarily land-controlling class) were landowners in a juridical sense, but rather "co-proprietors," the capitalist transformation of Romania's economy involved the boyars' property claims to land to which they had only feudal rights. This so-called re-enserfment of the peasantry was implemented with the help of a series of land reforms, which marked Romania's "shifting of the peripheral axis" (Bădescu 2003: 334) from its condition as a periphery of the Ottoman Empire to its incorporation into the capitalist world-economy as a periphery of Western Europe, supplying for the most part agricultural products under coerced labor. The liberal institutions necessary for this standardization of tenure arrangements as well as for similar modernization processes at the political, economic and cultural levels according to the Western capitalist model clashed with the country's immiseration and the growing cleavage between the new elites and the rest of the population. As a result, the increasing acuteness of social and especially peasant issues in the first decades of the twentieth century, alongside the influence exerted by foreign social doctrines such as Western socialism and the Russian Narodnik movement led to the appearance of a number of new political doctrines and cultural trends intended as responses, alternatives or modifications of either liberal policy or its various conservative counterparts. Their common denominator was the search for solutions to the unanimously acknowledged social and economic issues, but they diverged in terms of the explanations of backwardness offered and in the solutions suggested.

\section{SOCIALISM: A MARXIST ACCOUNT OF PERIPHERAL EVOLUTION}

Agreement upon the existence of a great discrepancy between Romania's liberal institutions and its economic reality, or upon what the most prominent Romanian socialist, Constantin Dobrogeanu-Gherea, termed "the abyss between the legal and the real land" placed an advocate of socialist ideas, at least on the theoretical level, in line with conservative thinking - a rather paradoxical position. ${ }^{2}$ In a much celebrated theory elaborated in 1868 , the conservatives

2. According to Wallerstein, this paradox is characteristic of socialist movements of the late nineteenth century. Among them, those located in the core would tend toward the social democratic approach, while the ones emerging in semiperipheral and peripheral zones placed under direct or indirect imperial rule viewed national liberation as the only means for achieving equality (Wallerstein 2002: 3I). 
had argued that modern society in Romania was reduced to the adoption of "forms without substance" from the West-that imported political and cultural superstructural elements did not foster progress, but rather concealed the hierarchical structures inherent in the relationship between Western and Eastern Europe, the better to exploit the latter. In view of the conservatives' argument that socialism itself was as contentless a form as the liberal institutions in a backward country, socialist theory faced the double pressure of credibly explaining the adoption of forms without substance in Marxist terms and legitimating its own existence in a country that was not, or, as Marxists would have it, not yet, capitalist.

\section{THE LAW OF THE HISTORICAL EPOCH}

The path that Gherea deemed congruent with a Marxist interpretation of history was that of agreeing with the conservatives that socialism, much like liberalism, was "an exotic plant" on Romanian soil, lacking such essential economic and social prerequisites as large-scale industry and a proletariat. Yet, in Gherea's view, this was no abnormal development, nor an instance of involution, but occurred in observance of a more general law of social evolution:

We are dealing with a general phenomenon of our social life, in that not only socialism is an exotic plant, but the entire life of our modern state is an exotic plant in a like manner; not only does socialism not result out of the deep social conditions of our national life, but most of the phenomena of our modern life fail to result from them in a like manner.... [W] are dealing with the very law of our social development, the law of the development of backward countries that lag behind in their social, their capitalist development. (Gherea 1908a: 48I)

The conservatives had condemned the adoption of forms without substance-land reforms to the detriment of the peasant majority, a liberal constitution borrowing heavily from Belgium's, a growing juridical apparatus representing the interests of Western capital and stunting the development of a national industry - as a costly mistake and as such, as an avoidable damage to Romania's evolution; Gherea, instead, attributed it a lawlike character and a wider historical scope. What at first glance might look like a justification of socialism's sterility based on the sterility of Romania's entire modernization represents the basis on which Gherea would attempt to render Romanian social history comprehensible by viewing it as an integral part of the world-systemic capitalist expansion. To this end, he had to qualify Marxist social theory so as to allow it to extend back to those regions of Europe which he considered part of a larger capitalist structure by virtue of their position on a sort of "degree of capitalism" scale. Following Marx, he thus insisted that "there are no eternal social laws," but that "every country, in every historical epoch of its development, has different classes, different antagonisms and different social laws.... Yet these laws, as abstract social laws, operate in their pure form... in advanced capitalist countries, like Belgium, Germany, England, and much more complexly and intricately in backward capitalist countries like our own" (Gherea I908b: 459f.).

Although it was precisely classifications of countries along an axis ranging from less to more capitalism which Immanuel Wallerstein charged with a unilinear view of evolution, Gherea's categorization into semicapitalist (or "backward capitalist") and capitalist societies managed to combine a teleological understanding of social development with a clear rejection of unilinearity. A Marxist in arguing that Romania had to overcome feudalism in order to attain "full" capitalism and eventually socialism, Gherea proved just as "un-Marxist" (Goldfrank 1988: 208) as Wallerstein in stating that the apparent idiosyncrasies Romania displayed in its transition to capitalism were a common trait of peripheral regions, and that such cases therefore were consistent with the rule, not exceptions to it. From this reinterpretation of evolutionary laws derived two separate implications that reveal an even stronger relatedness between Gherea's conception and Wallerstein's model of world-system analysis: one is a reassessment of the proper unit of analysis; and the other, a conspicuous emphasis on the exogenous factors of social change, or what Gherea termed "the totality of a country's social conditions":

When talking about the country's real social conditions, our sociologists isolate her in their mind from other countries and forget that, if our country is a socio-national organism, she still is part of another, superior social organism, she is in close relations of life and social conditions with other, more advanced countries, which to a great extent determine the conditions of our national life; they forget the bistorical capitalist epoch in which we are living and which influences and modifies the life processes going on in the country. (Gherea 1908a: 483; italics in original)

Unlike Wallerstein, however, Gherea did not formulate the problem of defining the unit of analysis of evolutionary processes in terms of replacing the focus on the nation-state by the notion of a capitalist system evolving as a whole. This stems both from the fact that Gherea did not have an exhaustive definition of the periphery (consequently, neither one of the core), as well as from the fact that he conceived of evolution as a twofold phenomenon, taking place at the level of the whole system, the "superior social organism," and within individual societies, or discrete "socio-national organisms." These-nevertheless 
severe-modifications of Marxist theory allowed him to formulate the "law of the historical epoch" as one pertaining to the whole system and as explaining the entire complex of "social phenomena specific to semicapitalist countries":

Backward countries enter the orbit of advanced capitalist ones, they move within the orbit of those countries and their whole life, development and social movement are determined by the historical epoch in which we are living, by the bourgeois capitalist epoch. And this determination of the life and social movement of backward countries by the advanced ones is their very condition of life. (Gherea I908a: 48I; italics in original)

The image Gherea presented was one in which an evolving integrated system of differently positioned societies had entered a period of social and economic transformations corresponding to the capitalist mode of production-the "historical epoch" of capitalism. Once the more advanced societies within the system had organized themselves around this mode of production, they could act upon the other societies making up the system such as to determine the timing and the pace of their individual evolution and attune it to their own, thus often triggering an acceleration of the backward countries' transition from one evolutionary stage to the other. The sequence of evolutionary stages remained a teleological process both at the level of the system and for individual societies, yet Gherea credited the "historical epoch" with a greater impact on systemic and societal evolution than the predetermined sequence of stages had in classical Marxism.

The paradox which this differentiation between historical epoch and internal stages of evolution made it possible to resolve was that, although both the causes and the implications of a transition to a new mode of production were mainly economic, the transformations they occasioned in the less advanced countries were predominantly of a social and institutional nature, i.e., superstructural. The terminology Gherea used when referring to the historical epoch as "bourgeois capitalist" on the one hand (implying both the economic and the social), and to its determining influence on backward countries as a process of "bourgeoisification"3 (implying superstructural change) on the other, does justice precisely to this distinction:

3. Here, again, there is a striking similarity with the emphasis Wallerstein placed on the creation of the bourgeoisie as a historical process of class formation, which he labeled with the same term Gherea had used as early as I892 — "bourgeoisification": "[T]o my knowledge, virtually no one speaks of 'bourgeoisification' as a parallel process to 'proletarianization'. Nor does anyone write a book on the making of the bourgeoisie....It is as though the bourgeoisie were a given, and it acted upon others: upon the aristocracy, upon the state, upon the workers" (Wallerstein 2000a: 333).
The basis of bourgeois society is production for exchange, so there is a need for free markets where products can be sold; that is why countries which do not possess the bourgeois social forms must be forced to admit the bourgeois principle of free trade. This is why we see England and France proceed to "bourgeoisify" with the help of their cannons, forcing even China and Japan into changing their products, and this is also why they do their best to civilize even the barbarians in Central Africa. (Gherea 1892: 433)

Arguably (still) within a Marxist discourse, Gherea in fact transferred the class struggle between the bourgeoisie and the proletariat from the level of the nation-state to that of the expanding (European) capitalist economy, in a less explicit, but no less clear manner than Immanuel Wallerstein would do in 1974. Writes Gherea:

Because of the tight links between all European and even American countries, the same economic law governs international relations which governs the different classes making up a state. Just as, in a state, that class which controls the means of production reigns over the other classes and imposes on them the social form which suits it, those countries whose means of production are highly advanced, whose production is well developed, also keep the other backward countries in economic bondage and impose on them their very social form. (Gherea I892: 432)

This shift in levels of analysis however meant a displacement of class struggle as a relevant factor of internal social change for individual (peripheral) societies, in which, consequently, "social transformations do not necessarily follow from class struggle, but are imposed from outside" (Gherea 1892: 435). At this point, Gherea unwillingly but clearly departed from conventional Marxism in his attempt at fleshing out a coherent explanation of peripheral evolution.

\section{NEOSERFDOM: THE UNINTENDED SEQUEL}

It was on the basis of his belief in the lawlike character of peripheral evolution that, in I9Io, Gherea would ground his explanation of Romania's "peasant question." After the violently repressed peasant uprisings of I888 and 1907, the critical condition of the peasantry-by far the overwhelming majority of the Romanian population-had incited an affluence of literature dedicated to explaining and possibly solving what had become Romania's central problem. In his own contribution to the ongoing debate, entitled "Neoserfdom. An Economic-Sociological Study of Our Agrarian Problem," Gherea argued that the mode of production instated in Romania after the land reform of I864 represented the most prominent instance of the coexistence of capitalist superstructural elements with a feudal economic base, a mixture made possible in the wake of Romania's incorporation into the "great world division of labor." Solving 
the resulting "agrarian issue" therefore was primarily a matter of acknowledging its specificity to Romania as a semicapitalist country.

From among the consequences of Romania's incorporation into the international division of labor, Gherea mentioned two as especially relevant to the situation of the peasant class: first, the transformation of the natural economy (i.e., one based on subsistence agriculture) into a monetized economy accompanying the growth of international trade, and second, the gradual disappearance of the peasant handicraft industry in the face of competition from cheap industrial products. ${ }^{4}$ Thus, while the feudal landlords became increasingly interested in overexploiting the peasants in order to extract more profit from the growing wheat exports, peasants were confronted both with an increase of their feudal dues to the lords and with the impossibility of supplementing their means through handicraft or wagoning.

A situation inherent to a transitional period from feudal relations of production to capitalist relations based on private property and wage labor, as Gherea viewed it, this contradiction between the juridicopolitical and socioeconomic structures could be resolved by organizing agricultural production (since there was yet no industrial production) around the capitalist principles which corresponded to the new political structures. The abolition of serfdom and the freeing of Gypsy slaves were steps toward such a gradual loosening of feudal ties, but the allotment of land according to the land reform of 1864 , Gherea contended, had stunted all development toward capitalist production, and had in fact reinforced and even worsened feudal relations. While allotment of land after the abolition of serfdom could occur in two different ways, either by benefitting the landowners and thus turning the former serfs into waged laborers, or by benefitting the peasants and hence centering around the exploitation of small peasant property, the law of 1864 represented a compromise between the two, "a hybrid, absurd, monstrous socioeconomical organism, that availed neither small property, nor large property rightly, but hindered both" (Gherea I910: 5I).

For Gherea, the "hidden tendency" of the first allotment of land, which in 1864 had distributed two-thirds of the village land to the peasants and the remaining third to the landlords, was "rendering the independent life of small property impossible" (Gherea I9IO: 54). By binding the peasants to the land, declaring their plots inalienable, and legalizing coerced work in the form of

4. For a comparison of Gherea's approach with Lenin's later thesis on the "Prussian" vs. the "American" route of capitalism's penetration of agriculture, see Stahl (I978: I Iof.). "labor contracts," the system had thus given a contractual form to the former feudal dues that the peasant had to provide to his master, i.e., it had reverted to a more radical form of serfdom. This particular regime, which had deprived the country of any possibility of development instead of providing a rational basis for it, was what Gherea termed "neoserfdom."

Authentic serfdom is no slavery; if it presupposes peasant dues to the lord, they are in their turn compensated by some landlord dues and obligations toward the peasant (providing land for work and land for the peasants' sons). These dues were eliminated by the law of 1864 , and large property became absolutely independent - to some extent a more characteristic and more purely bourgeois kind of capital than the Western one. Yet the capital of large property does not face a capitalist form of labor, free wage labor, but actually serf labor under the guise of contractual, coerced labor. Thus, we possess a double economical agrarian regime, an extraordinary regime: capitalist on the one hand, serf-based on the other, whose existence for half a century is due only to the extraordinary advantages it holds for our economically dominant class.

(Gherea 1910: 95; italics in original)

What Gherea described as "neoserfdom" was a form of labor control characteristic of the entire periphery of the capitalist world-economy from the sixteenth century on, one which Engels had labeled "second serfdom" in I888. Wallerstein had replaced Engels' concept in 1974 by the phrase "coerced cashcrop labor," meaning to draw attention to the fact that the "second serfdom" was not a return to feudal relations of production, nor an anomaly within a capitalist system, but, next to slavery, share-cropping, and tenancy, an alternative mode of labor control in those regions of the modern world-system in which wage labor was less profitable for the world-economy as a whole.

Romanian "neoserfdom" as a consequence of "the law of the historical epoch," while different from Engels' "second serfdom" both in its timing and its institutional superstructure, is more similar to Wallerstein's "coerced cash-crop labor" in stressing the twofold aspect of exploitation, fiscal and commercial, to which the peasants were subjected, but is not equivalent to it. Like Wallerstein, Gherea presented "neoserfdom" as a new form of the organization of production made possible by the capitalist penetration of Romania's economy. Unlike Wallerstein, he on the other hand still considered it anomalous because of its amalgamation of (formal) capitalist and (substantial) feudal features, whereas the American sociologist argued that the initially feudal elements had been redefined in terms of the governing principles of a capitalist system.

Industrialization, the completion of bourgeoisification by the adoption of universal suffrage, and the abolition of neoserfdom by ridding the economic organization of feudal remnants and replacing them with "true" capitalist rela- 
tions of production were both Gherea's solution to Romania's development and a reaffirmation of his teleological understanding of a specific evolution in the case of "semicapitalist" societies: "whatever the agrarian evolution of modern capitalist societies, the evolution of backward agrarian societies must pass through the bourgeois mode and relations of production" (Gherea 19IO: 410). Socialism, as once capitalism, was to reach Romania in the context of the next historical epoch, by drawing it into the new orbit of the countries having reached that stage.

\section{POPORANISM: THE UNRECOGNIZABLE LIBERATION MOVEMENT}

A cultural, political and economic program for which the national standpoint was a central one, yet whose position constituted a clear departure from both conservatism and socialism, was the one called "poporanism" as a sign of its focus on "the people" (Romanian popor). Emerging in the early I890s as a cultural movement centered around the notion of the intellectuals "duty" to emancipate the people, poporanism gradually expanded into the political and economic realms by advocating an agrarian and parliamentary reform along with universal suffrage, as well as the organization of agricultural production into cooperatives on the basis of small and mid-scale peasant holdings. On a political as well as theoretical level, poporanism acquired nation-wide prominence through its militant attitude toward socialism, particularly in the form of the heated debate between poporanism's founder, Constantin Stere, and Dobrogeanu-Gherea.

Most eminently, Stere's 1907 study "Social Democracy or Poporanism?" was an examination of Romania's agrarian structure in light of the applicability of socialist ideals to the particular Romanian context. Its central claim, in

5. These premises, alongside the fact that Constantin Stere had participated in, and been influenced by, the Russian Narodnik movement, easily stereotyped the new doctrine into a kind of populism more broadly, and in particular into a version of Russian narodnicism. Stere himself however claimed theoretical heritage from the German neo-Kantian school initiated by Eduard Bernstein in the late I89os, which marked the beginnings of a revisionist movement in Marxist theory and growing scepticism toward orthodox Marxism. According to Stere, there was a middle ground between socialism and liberalism, and, in the case of agrarian countries, this meant industrialization within the boundaries imposed by the society's peasant character and encouragement of small peasant property as the basis for economic development. Poporanism's originality, critics have noted (Georgiu 200I: I69), consists precisely in the extent to which its heterogeneous nature eludes dichotomies like traditional or modern, nationalist or democratic, "indigenist" or "Westernizing," left-wing or right-wing. keeping with the conservative view to which Gherea would react in 1908, was that socialism, and especially a socialist party, was a form without substance in Romania, a country in which the peasantry represented ninety percent of the population and in which the main social issue was the peasants' situation, not the proletariat's.

The scope of the socialist doctrine, Stere held, was a limited one both in space and in time, and the revisionist current among European socialists as well as the qualification of earlier views by some of the most orthodox socialists showed precisely these limits. Romania's case, Stere contended, proved correct Sombart's claim that "the limits of Karl Marx's system are in the agrarian question," thus adding to the mounting evidence against socialism's claim to universality. Estimating the size of the proletariat on the basis of the existing statistical data of the time, Stere concluded that factory workers represented less than one percent of Romania's population, while peasant tillers made up ninety-six percent of the country's taxpayers (see Stere 1996 [1907]: 47). Consequently, neither could the proletariat become a significant political force, nor did it represent Romania's "social category of work," overwhelmingly made up of a peasant class lacking both the social character and the political and moral attributes used to define the Western proletariat. A political party functioning on the basis of Western socialist doctrine in Romania would only treat a false issue, while disregarding the more obvious ones: "the burning social question which in Western countries resulted out of the capitalist development and the industrialization of production is not present as such in our own society, or is present under a wholly different guise - namely as the peasant question in all its variety and breadth, and not as a question of the proletariat, as in the West" (Stere 1996: 208; italics in original). Moreover, as a small agrarian state situated between three military powers and in a situation of cultural and economic backwardness permitting foreign intervention, Romania was faced with a national problem unknown to Western countries and therefore neglected by the internationalist doctrine of Western social democracy.

Furthermore, Marxist predictions with regard to the evolution of agriculture had proven false not only for agrarian countries, but for industrial ones as well. Stere thus attacked the socialist notion according to which the peasantry represented a petty bourgeoisie, a "remnant" of the old mode of production, and as such an enemy of the proletariat, condemned to disappear in the wake of the concentration of landed property into ever fewer hands. Using statistical data gathered by Eduard Bernstein for Western Europe and the United States, which pointed to the decrease of the latifundium system to the benefit of small and mid-size property - the exact reverse of what socialism had foreseen, Stere concluded, with Bernstein and Kautsky, that agricultural evolution followed 
different laws than those of industry, and that the minutely foretold "impasse of the peasantry" had rather turned into an "impasse of the social democratic doctrine in front of the peasantry" (Stere 1996: 34). Against this background, the viability and international competitiveness of those European economies centered on small-scale agriculture suggested that "purely agrarian" countries were by no means shut out from social progress, but that they had to conceive it as the outcome of a different evolution, specific to the social bases from which it could proceed. Thus, for Stere, the course of evolution was not predetermined and did not necessarily originate in the same social segment in every country. Rather, it was a function of the relation between a society's existing classes and the equidistant criterion of social progress, such that those classes whose interests coincided with the goal of general social progress were "positive social classes," in contrast to "those negative social elements that defend the old regime with its privileges and abuses, as the base of their dominant situation" (Stere 1996: 195).

While he viewed the Western industrial proletariat as "the only positive class from the point of view of social progress, since only its interests lie in the direction of universal progress," in agrarian countries such as Romania, unlike in the West, it was the peasantry that overwhelmingly represented the working class; this social category also became politically significant and could no longer assume the passive role that its counterpart played in industrial countries. While the peasantry alone did not possess revolutionary potential, the agrarian issue - as those countries' sole specific problem — had to be solved through the agency of the entire "social category of work" (made up of "the yeomanry," village teachers and priests, the small town bourgeoisie and the class of intellectuals) in accordance with the interests of the peasantry, its social tendencies, and the laws of agricultural evolution. In an agrarian country, therefore, a political party hoping to perform a central role in the local political landscape could only build its program upon the same interests and social tendencies as those of the peasantry; in short, it had to be a peasant party. The dogmatism of orthodox and revisionist Marxists which prompted them to insist on representing a "fictitious category" in agrarian countries, was the main factor responsible for the incapability of socialist doctrine to adapt itself to the socio-economic circumstances of those countries.

\section{THE THEORY OF "VAGABOND CAPITAL"}

Stere confronted Gherea's conviction that Romania, like other backward countries, would receive socialism from the outside, the role of a socialist party being that of smoothing out the transition, by claiming that "a country's politi- cal life cannot stand still until 'the day of the European social transformation,' and it is within this political life that we have a duty to fight for ensuring our country...the entire social, political and economic progress that we can achieve by ourselves" (Stere 1996: 183; italics in original). The decisive thing about Romania's subsequent evolution was therefore not so much the fact that it was an agrarian country, but that it was a backward agrarian country: the differences between Romania and Western industrial societies could not be explained in terms of inferior evolutionary stages, for they were structural, historically produced, and insuperable.

In order to ground his diachronical perspective ${ }^{6}$ on the origin of these structural differences, Stere turned to Sombart for proof that not only the laws governing agrarian evolution were distinct from those of industrial development, but the industrial beginnings of a backward agrarian country also faced social, economic and political circumstances very different from those encountered by advanced societies during the Industrial Revolution. The possibility of Romania's industrialization according to the Western model was ruled out because of the insufficiency of indigenous capital for financing large-scale industry, the irrecoverable lag between the industrial lead of advanced countries and Romania's small manufacturing beginnings, as well as the difficulties encountered by late industrializers faced with the control and pressure that the already industrialized countries exerted over both foreign markets and international politics.

6. As opposed to the synchronic perspective embraced by the vast majority of evolutionary theories, most notably those elaborated in the West. As Immanuel Wallerstein (I99I: I 52) noted using the example of orthodox Marxism, the idea that hegemonic states were models to be followed (Marx's "De te fabula narratur!") not only legitimated Eurocentrism, but made it mandatory as well. Consequently, for Eastern European (or otherwise peripheral) countries, "development" equalled "catching up," i.e., in the words of the neoliberal Ştefan Zeletin in the I920s, "synchronizing" with the West. It is against this view that Stere directed his criticism, coupled with his diachronic view of a multilinear evolution dependent on a country's socio-historical and political standing and its indigenous economic potential. That not only the imitation of Western political and economic models (as with synchronism) could be characteristic of peripheral regions, but also the anticipation of ideas and solutions to social, cultural and economic issues later to be dealt with in the West (a phenomenon consequently labelled "protochronism") was the response cultural historians gave to the synchronist ideology in the I970s and '80s. While the intellectual debate this provocative idea sparked cannot be addressed here, some of its implications for the Romanian contribution to theories of social change are briefly discussed below. 
Given that Romania was neither a colonial power, nor able to monopolize other countries' foreign trade as the nineteenth-century industrializers had, Stere's main argument concerned the importance of large foreign markets for placing the indigenous industrial products: "I agree with the most manifest kind of Marxism, when it states that without an external market there can be no large-scale modern industry, society's industrialization cannot follow and hence the industrial proletariat, with its specific social character, its firm political and economic role, cannot emerge and develop" (Stere 1996: 90; italics in original). Stere thus denounced protectionism as a "pathetic experiment," the creation of large-scale industry in Romania as a "dream," and the reversals of Western evolution in backward agrarian countries as indicative not simply of a different sequence of evolution, but of an entirely different course whose end point most likely was not, and could not be, industrial capitalism.

On the other hand, the growing intellectual uncertainty among Marxists in the face of nineteenth-century developments in the periphery was, for Stere, strong evidence that imperialist expansion, Marxism's failure to predict agricultural evolution in Western Europe, and the diminishing social antagonism between the bourgeoisie and the proletariat in England were intimately linked among themselves. Drawing on Kautsky's stipulation that a socialist transformation could only be expected from the workings of industrial capital, whereas the increasing amount of finance capital required for England's colonial expansion tended to mute its internal social evolution and class conflict, Stere claimed that the developments in England were the very result of social evolution and as such the vanguard of similar changes all over industrialized Europe. The evolution of backward countries, Stere argued, as that of the colonies gradually being incorporated into the European world-economy, was dependent upon the action of this newly created kind of capital, whose outcomes were indeed very different from those produced in the West in the nineteenth century:

In the civilized countries of the West, an immense commercial and finance capital was formed, which I labeled "vagabond capital," because this capital ransacks the world for a profitable investment, and because its field of operations lies mostly in the economically backward countries...In the countries in which it operates, this capital produces all the gloomy effects of capitalism, without compensating for them by the benefits which it has introduced in the West, because its effect in backward countries resides only in capitaliz ing incomes, but by no means in capitalizing the mode of production (which it is incapable of organizing there). Due to this fact, all the phenomena of "primitive accumulation" that Marx so forcefully described emerge there, but without a national wealth - which represented the historical justification of this phase in the West-emerging as well; the "vagabond capital" serves as a huge pump siphoning off abroad the wealth thereby accumulated. (Stere I996: II6f.; italics in original)

Elaborated as early as 1900 in order to address the socioeconomic realities created in the wake of the European and North American imperialist expansion, the concept of "vagabond capital" as Stere employed it in 1907 nevertheless managed to render a terse but faithful image of economic exploitation at the level of the entire capitalist world-economy ever since its emergence in the sixteenth century. Stere, of course, was primarily interested in a correct portrayal of Romania's economic prospects in the current political environment, and in particular with respect to the alleged inevitable path to socialism. Yet while the conceptual and theoretical lacunae of a hegemonic social science had prompted Gherea to resort to new definitions and laws meant to allow existing analytical categories to address the development of underdevelopment in backward countries, Stere's approach attempted to encompass both the social realities of the core and those in the periphery. The notion of "vagabond capital" on the one hand claimed explanatory power for the "bourgeoisification" of the proletariat in England (and for similar beginnings in Germany and the United States), which thus postponed the transition to socialism in those countries, and on the other hand, for the "proletarianization" of the entire work force in the exploited economies. In maintaining that "Vagabond capital, the foreign capital of backward countries, is none other than the commercial and finance capital-the antirevolutionary capital — of its country of origin" (1996: 120; italics in original), Stere located the causality of macrostructural change on a global level, i.e, he took the entire historical system as the unit of analysis capable of accounting for the development of underdevelopment:

If the economic process of the concentration of wealth at one pole and growth of the proletariat at the other, as a necessary prerequisite of social transformation, no longer takes place within the very capitalist country, but crosses its boundaries, while inside it, on the contrary, we encounter an increase of "capitalist magnates" alongside a decrease of the number of proletarians, who are themselves gradually turning into an aristocracy — then, obviously, this social transformation can no longer be accomplished within one state, but only at the level of a world revolution! (Stere 1996: I20; italics in original)

Not being a socialist and seeing the debates between the "revolutionary" and the "reformist" Marxists as proof of the socialist doctrine's internal contradictions and impracticality, Stere rejected the notion of a world revolution as a realistic solution to increasing social polarization and economic exploitation. Still, his "diagnosis of the world" matched the terms in which the Western socialists conceived social evolution to a considerable extent, as becomes clear from the numerous assenting references made about comments by Marx, 
Engels, Kautsky, or Liebknecht. Remarkably, part of this diagnosis was also the acknowledgment of Gherea's notion that the phenomenon of class struggle did not take place at the nation-state level, but on a global scale - an opinion which Stere, in the course of his polemics with the Marxist doctrine, came to defend more explicitly and outspokenly than Gherea himself. As Joseph Love has pointed out, the idea of "proletarian nations" was discovered independently more than once during the first decades of the twentieth century by Marxist and Marxist-influenced intellectuals entertaining a center-periphery view of world economic structures (Love 1996: 175). Among them, Gherea "skirted close to the idea" in I892, Lenin "came close to adopting the notion" in 1916, while Constantin Stere, Enrico Corradini, and Li Ta-chao "discovered" it (idem) between 1908 and 1920. Given that the perspective would only become formalized after World War II within dependency theory (see Emmanuel 1972) and virtually "institutionalized" within world-systems analysis, its emergence in turn-of-the-century Romania in the context of a controversy with orthodox Marxism and rejection of unilinear evolutionism, and its continuity over the length of the debates around the theory of forms without substance speaks for the fecundity of a peripheral standpoint and the visionary insights inherent in the poporanist theory of "vagabond capital."

The strong corrective which Stere therefore applied to the socialist agenda of an international struggle against "capitalism" as an undifferentiated mode of production entailed that it was only in core countries that social evolution expressed itself in the form of a class struggle between the bourgeoisie and the proletariat. In peripheral countries, in the absence of the industrial capital responsible for the rise of the Western bourgeoisie and the formation of the Western proletariat, the social structure did not mirror that of core countries, nor was underdevelopment the outcome of social polarization, but of the action of a particular kind of capital, producing a particular kind of capitalism based on fiscal exploitation through local foreign agents. Consequently, the peripheral countries' contribution to a world socialist revolution could only take the form of a national struggle against this type of capital, incapable of organizing capitalist production in the countries which it penetrated and responsible for the antirevolutionary tendencies in its countries of origin.

With his attempt at reconciling the national and the international character of class struggle, Stere not only managed to ideal-typically argue for divergent evolutionary paths for industrial and agrarian countries - an issue still very much on the agenda of current globalization debates - but also came very close to a world-systems perspective on class analysis. In 1979, Immanuel Wallerstein would account for the "partial muting of the class conflict of the core countries" in strikingly similar terms:
[I]n general, in a capitalist world-economy, the primary contradiction within core areas is to be located in the quarrel over the ambiguous and ambivalent role of the state structure, whose control is sought by different groups, both primarily located within its boundaries. This struggle, when it is sharp, is national in scope and class conscious in terminology. This is what comes within the usual image of "class analysis." In peripheral areas of the worldeconomy, however, the primary contradiction... is between the interests organized and located in the core countries and their local allies on the one hand, and the majority of the population on the other. In point of fact then, an "anti-imperialist" nationalist struggle is in fact a mode of expression of class interest. (Wallerstein 1979: 200; italics in original)

Marxist terminology, a periphery-based outlook on imperialism, denunciation of the destructive role of the local bourgeoisie, and denial of the revolutionary potential of the indigenous industrial proletariat have been common traits of more than one intellectual current, and have since the 1960 s been increasingly associated with neo-Marxism and the Latin American dependency school. Despite the similarities between his own approach and those of dependency and world-systems analysts, Stere parted company with socialist or (neo-)Marxist accounts as soon as conclusions about future prospects had to be drawn from the partly overlapping diagnoses. From a poporanist standpoint, not only could Romania not pursue a revolutionary development policy, but any reforms in a "peasant state" had to center around the economic strengthening of the peasantry as "society's undifferentiated basis." The logical sequel to the I 848 revolution, the fulfillment of the incomplete beginnings of institutional democratization, Stere argued, could only occur within the framework of a rural democracy, established on the basis of a peasant class emancipated both politically (through universal male suffrage) and economically (through proper allotment of land). Institutionally, this form of organization in which the constitutional principle of "people's sovereignty" was indeed granted to the mass of the people, the peasantry, could thus resolve the discrepancy between formal modernization and economic backwardness. Economically, as well, the only viable alternative to the large external markets available to industrial countries was a small peasant industry primarily intended as production for use and as the social cradle of an inchoate national petty bourgeoisie (Stere 1996: 215). Proclaims Stere:

A free landowning peasantry; the development of the occupational structure and of small-scale industry, with the help of a corporative movement both in towns and in the countryside; state monopoly of large-scale industry (save for exceptional cases in which it could develop by itself, without harming economic life); this is the formula of our economic and social progress as imposed by the very circumstances of our national life. (Stere 1996: 225) 
A program later to be almost literally adopted and expanded by the interwar theoreticians of Romanian peasantism, the poporanist formula for economic progress has often been interpreted as an anti-industrialist, anticapitalist stance, in particular as an opting out of the capitalist world-economy (e.g. Gherea I9IO: 488; Stahl 1978: II2; Love 1996: 34). Above all, the notion of a corporative system of agriculture, ${ }^{7}$ grounded in the rejection of the Marxist model of the gradual disappearance of individual peasant property and meant by poporanists as a form of resistance to the exploitive action of financial capital would be strongly denounced by Marxist opponents of anti-imperialism (see Lenin 1956: 174). In fact, as peasantist and corporatist Romanian authors would prove in later decades, the corporative system did not represent an alternative to a capitalist economy, but a capitalist alternative to industrialized economies. Likewise, poporanism did not advocate skipping the capitalist stage, as many analysts, following Gherea (Gherea 1910: 490), believed, but the impossibility of achieving industrial capitalism in Romania, that decisive stage of capitalist evolution which Marxists often mistook for capitalism itself. ${ }^{8}$

One could conclude that the confrontation with the Marxist doctrine was the great chance and the great misfortune of poporanism: on the one hand, it lent it a terminological apparatus enjoying great currency at the time, instantly recognizable even when modified (as in "vagabond capital"); on the other, it

7. Agricultural cooperatives were a measure for directly linking agricultural production to the capitalist market, without exposing individual small-scale property to fiscal exploitation through the credit system and the commercial apparatus (cf. Stere I996: 215).

8. Wallerstein has traced back the confusion between industrialism and capitalism to the era of the industrial revolution, in which the debates between Marxists and liberals on the nature of capitalism took place. Marx's distinction between merchant and industrial capital, Wallerstein noted, was an attempt to deal with this confusion, but one which had still left the capitalist phase before the industrial revolution terminologically unaccounted for (see Wallerstein 20oob: 83ff.). It was in this context that Wallerstein proposed the term "agricultural capitalism" for the period preceding the industrial revolution, thus stressing its character as (non-industrial) production for sale and profit. In 1907, Stere's attempt to impose a similar distinction between the capitalism of industrial countries and the one based on agricultural production prompted both Marxist and liberal authors to ground their rejection of his model on the same rigid definition of capitalism that Wallerstein was attempting to overcome. To this day, this attitude earned poporanism the reputation of being an anticapitalist current. established stereotypical judgments whose inflexibility was rooted precisely in the authority and currency of Marxist doctrine.

More than in any other previous current, the often-cited poporanist "paradoxes" (geopolitical cosmopolitanism versus economic and cultural nationalism, opting for modernization but against unilinear evolution, agreement with Marxist views versus rejection of Marxist conclusions) mirror the extent to which the clash between the Western "global designs" and Romanian "local history" (Mignolo 2000) had to be filtered through a critical attitude capable of resignifying the former in conformity with the latter's needs. Consequently, for poporanists, the stance according to which modernization no longer was Westernization for the first time took the form of a coherent doctrine which advocated the discarding of the liberal myth and exploring the indigenous potential without, however, opting out of the (world-)system.

Condemned to silence for several decades within Romania, ${ }^{9}$ Gherea's and Stere's consequential findings on unequal exchange, global class struggle and the circulation of capital gained only partial and indirect international recognition when taken up by Corporatist Party leader and economist Mihail Manoilescu, the "godfather of the general argument" (Schmitter 1978: 12I), and subsequently by the Prebisch-Cepal school. In particular, Manoilescu's controversial contention that the displacement of forces of production from lowproductivity agriculture to high-productivity industry was inherently advantageous entered post-war development debates (in the Iberian Peninsula as well as in Latin America) as "the Manoilescu argument" and was endorsed and later developed by Raúl Prebisch and Celso Furtado (Love 1996: 83), among others.

9. Gherea's reformist stance toward the Marxist dogma and his affiliations with the conservative theory of "forms without substance" attracted him charges of opportunism, disregard for scientific socialism and for the aims of the workers' movement, as well as of plain "Anti-Marxism" from the communist regime installed in Romania after 1945. His books were consequently banned from publication until the late I960s, when a process of partial recuperation began. In contrast, Stere's openly anti-Marxist series of articles, "Social-Democracy or Poporanism?," branded as "reactionary," "diversionist," and "pettybourgeois" remained unpublished in book form until I996 (!) and his work was completely excluded from intellectual debates for the whole duration of communist rule. It is only in recent years that the interconnectedness between the theory of "forms without substance," the politically highly divergent arguments it spawned at the turn of the twentieth century, and the issue of structural dependency resurfaced in academic discussion of theories of social change within and outside Romania. 
In the United States, the claim for Romanian sociology's precedence in dealing with several central issues of modern development debates was staked out as early as $1978^{10}$

Paradoxically, it is only in Romania itself that the legitimacy of the claim is still disputed: while one side of the intellectual elite prioritizes retracing, recuperating and restoring to (international) collective memory those dimensions of Romanian culture and history interdicted or distorted under communism (Bădescu and Ungheanu 2000), the newly revived possibility of "synchronizing with the West" after the fall of communism prompts the opposing camp to minimize or even dismiss specific Romanian contributions as irrelevant and to condemn their supporters for singling out local, past achievements instead of focusing on integrating present-day Romania into larger political, economic and cultural structures.

At least in the case of the contributions to theories of social change dealt with in this article, however, the claim to precedence is not a claim to genius. On the contrary, as with Latin American dependency theory, it was Eastern Europe's peripherality with respect to Western Europe that prompted the innovative reinterpretation and modification of Western development policies. As the entire periphery of the modern world-system was being affected by the successive global designs brought forth by Occidental ideology, the reinvention and independent discovery of critical theories in response to particular historical and social circumstances represented the corresponding answers to such designs on the part of local histories.

10. In the printed version of a talk given at the Berkeley Institute of International Studies in 1978, Daniel Chirot opened his analysis of neoliberal and social-democratic development debates in early twentieth century Romania with the words: "For a contemporary American sociologist steeped in the debates currently at the fore of macrosociological theory, it is startling and sobering to discover that in the I920s some Romanian intellectuals were engaged in essentially the same controversies, and that their polemic was conducted on a level at least as sophisticated as that of today" (Chirot I978: 3 I).

\section{REFERENCES}

Bădescu, Ilie. 2003. Sincronism european şi cultură critică românească [European Synchronism and Romanian Critical Culture]. Cluj-Napoca: Ed. Dacia

Bădescu, Ilie, and Mihai Ungheanu, eds. 2000. Enciclopedia valorilor reprimate [The Encyclopedia of Repressed Values]. Bucharest: Pro-Humanitate.

Boatcă, Manuela. 2003. From Neoevolutionism to World-Systems Analysis. The Romanian Theory of "Forms without Substance" in Light of Modern Debates on Social Change. Opladen: Leske + Budrich.

Chirot, Daniel. 1976. Social Change in a Peripheral Society: The Creation of a Balkan Colony. New York: Academic Press

Chirot, Daniel. 1978. "Neoliberal and Social-Democratic Theories of Development." PP. 31-52 in Social Change in Romania, 1860-1940, edited by Kenneth Jowitt. Berkeley: University of California Press.

Dobrogeanu-Gherea, Constantin. I892. "Rolul Păturii Culte în Transformările sociale" [The Role of the Cultured Layer in Social Transformations]. PP. 426-46 in Opere complete, vol. 2. Bucharest: Ed. Politică, 1976.

. I908a. "Post-scriptum sau Cuvinte uitate" [Postscript or Forgotten Words]. PP. 476-504 in Opere complete, vol. 2. Bucharest: Ed. Politică, I976.

. 1908b. "Un mic răspuns la o mică recenzie" [A Short Answer to a Short Review]. PP. 454-75 in Opere complete, vol. 3. Bucharest: Ed. Politică, 1976. - I910. Neoiobăgia. Studiu economico-sociologic al problemei noastre agrare [Neoserfdom. Economico-Sociological Study of Our Agrarian Problem]. Bucharest: Socec.

Emmanuel, Arghiri. 1972. Unequal Exchange: A Study of Imperialism of Trade. New York: Monthly Review Press.

Georgiu, Grigore. 200I. Identitate şi integrare. De la disjuncție la conjuncție [Identity and Integration. From Disjunction to Conjunction]. Bucharest: Institutul de Teorie Socială.

Goldfrank, Walter. I988. "The Intellectual Background of Immanuel Wallerstein and his World System." Modern Praxis 7 (March): 206-222.

Lenin, Vladimir Illytch. 1956. The Development of Capitalism in Russia: the Process of the Formation of a Home Market for Large-Scale Industry. Second edition. Moscow: Progress Publishers.

Love, Joseph L. 1996. Crafting the Third World: Theorizing Underdevelopment in Rumania and Brazil, Stanford, CA: Stanford University Press.

Mignolo, Walter. 200o. Local Histories/Global Designs: Coloniality, Subaltern Knowledge, and Border Thinking. Princeton, NJ: Princeton University Press.

Schmitter, Philippe. 1978. "Reflections on Mihail Manoilescu and the Political Consequences of Delayed-Dependent Development on the Periphery of Western Europe." pp. II7-39 in Social Change in Romania, 1860-1940, edited by Kenneth Jowitt. Berkeley: University of California Press.

Stahl, Henri H. 1978. "Théories de C.D. Gherea sur les lois de la pénétration du capitalisme dans les 'pays retardataires'." Review 2 (I): IOI-II4. 
Stere, Constantin. 1996. Social-democratism sau poporanism? [Social Democracy or Poporanism?]. Galați: Porto Franco. (Originally published in 1907-I908.)

Wallerstein, Immanuel. 1979. "Class and Class Conflict in Contemporary Africa."

PP. 193-202 in The Capitalist World-Economy. Cambridge, Eng.: Cambridge

University Press.

I99I. "Marx and Underdevelopment." PP. I5I-69 in Unthinking Social Science.

Cambridge, Eng.: Polity Press.

2000a. "The Bourgeoisie as Concept and Reality." Pp. 324-43 in The Essential

Wallerstein. New York: The New Press.

200ob. "The Rise and Future Demise of the World Capitalist System." pp.

7I-105 in The Essential Wallerstein. New York: The New Press.

. 2002. "New Revolts Against the System." New Left Review I8 (Nov./Dec.):

29-39. 